\title{
Administrative assessment in emergency medicine: a tool of impact
}

\author{
Anne Fischer Sørensen, Annika Wieslander, Anne Grethe Mølbak \\ From Danish Society for Emergency Medicine: Research Symposium 2010 \\ Roskilde, Denmark. 20-21 May 2010
}

\section{Background}

The Department of emergency medicine was established one year ago. One of our main goals is to ensure correct initial treatment, stabilisation and referral to the correct speciality, of all patients admitted to the hospital. In optimising the process of triage and referral, all young doctors have to consult a coordinating doctor (i.e. a more experienced doctor) before initialising treatment, deciding on a diagnosis and referring to another speciality. This coordinating function is essential in the treatment of the patients and the patient flow in the emergency department. In order to improve the two coordinating doctors' (i.e. the authors) referral skills, a study monitoring the clinical outcome of all patients treated in a certain period was performed.

\section{Methods}

A review of all the patients admitted to the hospital during 5 random workdays was outlined. All cases were analysed by diagnosis and referred speciality, at discharge from the emergency department and at discharge from the hospital. Data was split into four main categories: 1) correct diagnosis, correct speciality; 2) incorrect diagnosis, correct speciality; 3 ) incorrect diagnosis, incorrect speciality; 4) immediate patient discharge. Further subdivisions were formed to analyse the results in more detail.

\section{Results}

185 patients cases were analysed and categorised as followed; 1) $53 \%$; 2) $30 \%$; 3) $5 \%$; 4) $12 \%$.

\section{Conclusion}

Assessment of coordinating doctors, using patient outcome data is useful, in both an individual and in a

* Correspondence: agmo@regionsjaelland.dk

Department of Emergency Medicine, Køge Sygehus, Denmark general perspective. The method supports the coordinating doctor in understanding and developing diagnostic and referral skills in emergency clinical settings.

Our study showed that $93 \%$ of all the patients in the study were treated and referred in the most appropriate way, but the part of patients in group 1 was only $53 \%$ which leaves room for improvement.

To improve the communication between the young doctor and the coordinating doctor, a pocket guide was made. Future studies will test if this communicative tool can improve diagnostics and referral in the emergency department.

Published: 17 September 2010

\section{doi:10.1186/1757-7241-18-S1-P2}

Cite this article as: Sørensen et al:: Administrative assessment in emergency medicine: a tool of impact. Scandinavian Journal of Trauma, Resuscitation and Emergency Medicine 2010 18(Suppl 1):P2.
Submit your next manuscript to BioMed Central and take full advantage of:

- Convenient online submission

- Thorough peer review

- No space constraints or color figure charges

- Immediate publication on acceptance

- Inclusion in PubMed, CAS, Scopus and Google Scholar

- Research which is freely available for redistribution

Submit your manuscript at www.biomedcentral.com/submit
C Biomed Central 